\title{
Папа Бенедикт XVI: філософ, політик, дипломат
}

\author{
Данилюк І.В., Київський національний університет імені Тараса Шевченка
}

Бенедикт XVI (lat. Benedictus PP XVI) - заслужений Папа Римський, 265-й Папа Католицької церкви i єпископ Рима та 7-й правитель міста-держави Ватикан із 19 квітня 2005 року по 28 лютого 2013 року.

3 обранням Папи Бенедикта XVI вважалося, що папство Німецького Папи стане досить консервативним, натомість правління 265-го Папи було ознаменоване низкою нововведень, реформ та нових ідей.

Бенедикт XVI за свої менше ніж вісім років понтифікату здійснив ряд реформ у Католицькій Церкві, але слід відзначити, що ще до вступу на Апостольський Престол Джозеф Ратцінгер, майбутній Папа Бенедикт XVI, був одним із тих, хто визначав обличчя сучасної Католицької церкви під час Другого Ватиканського Собору, а також у подальшій роботі на найвищих посадах у Католицькій церкві та Ватикані у тіні Папи Івана-Павла II.

В статті було відзначено, що папство Бенедикта XVI не зосереджується на політиці, а більше на написанні творів. Папа не відмовляється від політичних дій та дипломатичних кроків, а, відповідно до німецького стилю, делегує політику і дипломатію компетентним особам. Було зазначено, що у своїх роботах Бенедикт XVI піднімав важливі соціальні та етичні питання, а енцикліка «Caritas in Veritate», яка була відповіддю на фінансову кризу 2008 року, стала світовим бестселером. Варто звернути увагу на послання Бенедикта XVI, які завжди ішли до самої проблеми та піднімали актуальні проблеми світового співтовариства.

Особливість фігури Папи Бенедикта XVI можна прочитати двома способами: по-перше, важливість аналізу філософських поглядів, політичних закликів і кроків Папи Бенедикта XVI; по-друге, через своє історичне минуле Джозеф Ратцінгер (майбутній папа Бенедикта XVI) у силу обставин перебував у Гітлерюгенд та брав участь у Другій Світовій війні, але не втратив свого людського обличчя

Бенедикт XVI виступає прикладом здатності людини зі скромним походженням робити великі речі і добиватися визнання. Найбільш величним, на думку автора, у постаті Папи Бенедикта XVI $є$ уміння робити важливий та відповідальний вибір: будучи главою Католицької церкви, відмовитись від влади, поступившись більш молодим та енергійним.

Ключові слова: Бенедикт XVI; Католицька церква; Святий Престол; Ватикан

\section{Pope Benedict XVl: philosopher, politician, diplomat}

\section{Danyliuk I.V., Taras Shevchenko National University of Kyiv}

Benedict XVI (lat. Benedictus PP XVI) - Pope Emeritus, 265-th Pope of the Catholic Church and Bishop of Rome and the 7th governor of Vatican City State from 19 April 2005 to 28 February 2013.

With the election of Pope Benedict XVI, it was known that the papacy of the German Pope would become rather conservative, but the governance of the 265-th Pope was marked by a number of innovations, reforms and new ideas.

For less than eight years, Benedict XVI had made a number of reforms in the Catholic Church, but before to lead the Holy See and the Catholic Church, Joseph Ratzinger, the future Pope Benedict XVI, co-defined the face of the modern Catholic Church during the Second Vatican Council, as well as in further work on the highest positions in the Catholic Church and the Vatican.

Also, it was noted that the papacy of Benedict XVI is not focusing much on politics, and more on the writing of scientific works, Encyclicals and messages. The Pope does not renounce political actions and diplomatic steps, but, according to the German style, delegates politics and diplomacy to competent persons. It should be noted that in own works Benedict XVI raised important social and ethical questions, furthermore in addition the Encyclical of Benedict XVI «Caritas in Veritate; which was the response to the 2008 financial crisis, became the world's bestseller. Pope Benedict XVI is a great intellectual of the Catholic Church, author of a number of works on Christianity and three Encyclicals. It is worth paying attention to the message of Benedict XVI, who always went to the very problem and raised the actual problems of the world community.

The figure of the Pope always attracts attention and is an example of imitation, since the head of the Catholic Church is an example for imitation his believers, as well as a moral judge on the international arena.

The peculiarity of the figure of Pope Benedict XVI can be read in two ways: firstly, the importance of the analysis of the philosophic views, political appeals and steps of Pope Benedict XVI; and the secondly, because of his life, which, in the circumstances, Joseph Ratzinger future pope Benedict XVI had been in the Hitlerjugend and took part in the Second World War, but did not lose his human face.

Benedict XVI is an example of the ability of a man with modest origin to do great things and get recognition. The most magnificent, according to the author, in the figure of Pope Benedict XVI is an example to make an 
important and responsible choice: being the head of the Catholic Church he refuses from power, giving way to a younger and more energetic.

Keywords: Benedict XVI; Catholic Church; Holy See; Vatican

\section{Папа Бенедикт XVI: философ, политик, дипломат}

\section{Данылюк И.В., Киевский национальный университет имени Тараса Шевченко}

Бенедикт XVI (lat. Benedictus PP XVI) - заслуженный Папа Римский, 265-й Папа Католической церкви и епископ Рима, 7-й правитель города-государства Ватикан с 19 апреля 2005 по 28 февраля 2013 года.

C выбором Папы Бенедикта XVI было известно, что папство Немецкого Папы станет достаточно консервативным, однако правление 265-го Папы было ознаменовано рядом новшеств, реформ и новых идей.

Бенедикт XVI за свои менее чем восемь лет понтификата совершил ряд реформ в Католической церкви, но еще до вступления на Апостольский Престол Джозеф Ратцингер (будущий Папа Бенедикт XV), был одним из тех, кто определял лицо современной Католической церкви во время Второго Ватиканского Собора, а также в дальнейшей работе на высоких должностях в Католической церкви и Ватикане в тени Папы Ивана-Павла II.

Также было отмечено, что папство Бенедикта XVI не сосредотачивается на политике, а больше на написании трудов. Папа не отказывается от политических действий и дипломатических шагов, а, согласно немецкому стилю, делегирует политику и дипломатию компетентным лицам. Следует отметить, что в своих трудах Бенедикт XVI выдвигал важные социальные и этические вопросы, а энциклика «Caritas in Veritate», которая была ответом на финансовый кризис 2008 года, стала мировым бестселлером. Стоит обратить внимание на послание Бенедикта XVI, которые всегда шли к самой проблеме и поднимали актуальные проблемы мирового сообщества.

Особенность фигуры Папы Бенедикта XVI можно прочесть двумя способами: во-первых, важность анализа философских взглядов, политических призывов и шагов Папы Бенедикта XVI; и, во-вторых, через свое историческое прошлое Джозеф Ратцингер (будущий папа Бенедикта XVI) в силу обстоятельств находился в составе Гитлерюгенд и участвовал во Второй мировой войне, но не потерял своей человечности.

Бенедикт XVI выступает примером способности человека со скромным происхождением делать великие вещи и добиваться признания. Наиболее величественным, по мнению автора, в личности Папы Бенедикта XVI является умение делать важный и ответственный выбор: будучи главой Католической церкви, отказаться от власти, уступив более молодым и энергичным.

Ключевые слова: Бенедикт XVI; Католическая церковь; Святой Престол; Ватикан

\section{Постановка проблеми:}

$\Pi$ остать Папи завжди привертає увагу, адже глава Католицької церкви виступає прикладом для наслідування перед своєю паствою, а також моральним суддею на міжнародній арені.

Особливість постаті Папи Бенедикта XVI можна прочитати у двох ключах: по-перше, важливість аналізу філософських поглядів, політичних закликів та кроків Папи Бенедикта XVI; по-друге, через своє історичне минуле, адже Джозеф Ратцінгер в силу обставин перебував у Гітлерюгенд та брав участь у Другій Світовій війні, але не втратив свого людського обличчя.

Аналіз останніх джерел і досліджень:

Для аналізу постаті Бенедикта XVI використано біографію Папи з офіційного сайту Ватикану «Biografia di Sua Santità Benedetto XVI» [9], a raкож напрацювання А. Меллоні «Enciclopedia dei Рарі» [15]. Цікаві матеріали знаходимо в деяких тематичних статтях $[1,12,17,19]$, які розкрива- ють деякі сторінки з життя майбутнього Папи Бенедикта XVI.

Філософські погляди та політичні заклики знаходимо у енцикліках Бенедикта XVI «Caritas in Veritate» [4], «Deus caritas est» [5] та посланнях Папи «Послання до Генеральної Асамблеї ООН» [6], «Послання до XXXIX Всесвітнього дня миру» [7].

Аналіз політичних та дипломатичних кроків Папи Бенедикта XVI знаходимо в статтях Т. Джодока «The Catholic Church: An Underestimated and Necessary Actor in International Affairs» (Католицька церква: недооцінений та необхідний актор у міжнародних справах) [13], Е. Пентіна «The Pope as Diplomat. How the Vatican Does Foreign Policy» (Папа як дипломат. Як Ватикан займається зовнішньою політикою) [16].

Мета статті: дослідити постать Папи Бенедикта XVI. Поставлена мета формує наступні завдання статті: проаналізувати біографію Бенедикта XVI, розкрити філософські погляди, охарактеризувати політичну та дипломатичну діяльність папи Бенедикта XVI. 


\section{Виклад основного матеріалу:}

Джозеф Алоїс Ратцінгер (Joseph Aloysius Ratzinger), майбутній Папа Бенедикт XVI, народився 16 квітня 1927 року в Марктл-ам-Інн

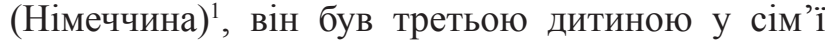
Mарії та Джозефа Ратцінгер [15]. Батько був комісаром жандармерії, походив із бідної сім'ї фермерів Нижньої Баварії. Мати була дочкою ремісників з Баварії [15].

Час молодості був нелегким для майбутнього Папи. Віра й освіта його сім'ї підготували Джозефа Ратцінгера до суворого досвіду проблем, пов'язаних із нацистським режимом. Родина Ратцінгера, особливо батько, були в опозиції до нацизму ${ }^{2}$, а позиція батька проти нацизму призвела до пониження в посаді та переслідуванні сім'ї [14]. Бенедикт XVI згадував, що «бачив побиття свого пастора нацистами перед святкуванням Святих Мес і відчував клімат сильної ворожнечі у конфронтації з Католицькою церквою в Німеччині» [9]. Джозеф Ратцінгер також зустрівся із жахом програми евтаназії інвалідів нацистського режиму: «Ратцінгер мав двоюрідного брата з синдромом Дауна. В 1941 році йому було 14 років, на кілька місяців молодший від самого Ратцінгера, був забраний нацистською владою на «терапію». Через деякий час сім'я отримала звістку про те, що він помер, імовірно був визнаний одним із «небажаних» того періоду і ліквідований» [1].

Хоча батьки мали певні матеріальні труднощі у 1939 році, у віці 12 років Джозеф Ратцінгер вступив у перед-семінарію в Траунштайні [2, с. 14]. У 1941 р він вступив до семінарії і тоді ж поповнив ряди Гітлерюгенд ${ }^{3}$ (Hitlerjugend) вступ у Гітлерюгенд був обов'язковим відповідно до вимог закону Gesetz über, який зобов'язував до членства в Гітлерюгент всіх 14-річних німецьких юнаків. Сам Джозеф Ратцінгер у знак протесту відмовився від участі в засіданнях Гітлерюгенд. Проблем юному Ратцінгеру вдалося уникнути завдяки розумінню професора математики, що дозволило йому пропускати засідання Гітлерюгенд. У семінарії Джозеф Ратцінгер залишався до 1942 року, коли семінарія була закрита для використання у військових цілях, а семінаристи були відправлені додому. Тоді Джозеф Ратцінгер іде до гімназії в Траун- штайні [2, с. 15]. У 1943 році з гімназії він був зарахований у корпус протиповітряної оборони Luftwaffenhelfer в батарею, яка повинна була захищати завод авіадвигунів BMW на околицях Мюнхена від повітряних нальотів. У 1944 році, досягнувши призовного віку, був призваний до армії в Австрійський легіон. Джозефа Ратцінгера направили на австро-угорський кордон на установку протитанкових мін [17].

Навесні 1945 року Джозеф Ратцінгер дезертирував 3 армії і попрямував додому в Траунштайн. Будучи німецьким солдатом, він був арештований американцями та інтернований у таборі військовополонених, але звільнений через кілька місяців - 19 червня1945 року [15].

Попри службу в армії, у період війни Джозеф Ратцінгер не брав участі в самих бойових діях. Слід відзначити, що будучи кардиналом, Джозеф Ратцінгер, а пізніше Папа Бенедикт XVI, не приховував свого членства в Гітлерюгенд, а також участі у Другій світовій війні на боці Німеччини.

Уже в листопаді 1945 р. Ратцінгер знову повертається до семінарії. Після завершення семінарії у 1946 році Джозеф Ратцінгер вступаю до Вищого інститут філософії і теології у Фрайзінгу, де він вивчав філософію і теологію, незабаром у 1947 році Ратцінгер переїхав до Мюнхену де вступив у Богословський інститут при Мюнхенському університеті [15].

29 червня 1951 року, на свято Петра і Павла за Католицьким стилем, Джозеф Ратцінгер був висвячений на священика у соборі Фрайзінга кардиналом Фаульхабером - архієпископ Мюнхена і Фрайзінга. Через рік Джозеф Ратцінгер почав викладати у Вищій школі філософії і богослов'я Фрайзінга [9].

У 1953 р. Джозеф Ратцінгер захистив дисертацію, присвячену еклезіології Августина в Мюнхенському університеті. Другу дисертацію він присвятив богослов'ю історії у Святого Бонавентури [9].

У 1959-1977 роках Джозеф Ратцінгер викладав фундаментальне богослов'я в університетах Німеччини: в Бонні (1959-1969), в Мюнстері (1963-1966) і Тюбінгені (1966-1969). 31969 р. він був професором у Регенсбурзькому університеті, де також обіймав посаду заступника ректора [9].

${ }^{1}$ У 1929 році сім’я Ратцінгерів переїхала в Тіттмонінг, а в грудні 1932 року в Ашау-ам-Інн, де Джозеф навчався в початковій школі. У квітні 1937 року, після перемоги націонал-соціалістичного режиму, Ратцінгери переїхали в Траунштайн [15].

${ }^{2}$ Старший брат Бенедикта XVI Георг Ратцінгер згадував про їхнього батька: «Він був заклятим ворогом нацизму, тому що вважав, що це буде суперечити нашій вірі» [14].

${ }^{3}$ Гітлерюгент (Hitlerjugend) - юнацька воєнізована націонал-соціалістична організація, членство у якій, відповідно закону Gеsеtz ӥber, було обов'язковим для всіх німецьких підлітків віком від 14 до 18 р. 
Інтенсивна наукова діяльність ${ }^{4}$ привела Джозефа Ратцінгера до виконання важливих завдань на німецькій єпископальній конференції у Міжнародній богословській комісії [9].

У 1962-1965 роках в якості радника-теолога при кардиналі Джозефі Фрінгусе Джозеф Ратцінгер брав участь у роботі Другого Ватиканського Собору. Сам Бенедикт XVI називав участь в II Baтиканському Соборі центральною подією у житті, що також «підтвердила його покликання, визначеного ним як «теолог» [9].

У 1972 році Джозеф Ратцінгер разом із Гансом Урсом фон Бальтазаром, Анрі де Любаком, Вальтером Каспером та іншими засновують міжнародний католицький журнал Communio («Причастя») $)^{5}$, який був присвячений питанням богослов'я і культури. Журнал,публікований на сімнадцяти мовах, включаючи німецьку, англійську та іспанську, став провідним журналом католицької теологічної думки на сучасному горизонті [10].

25 березня 1977 р. Джозефа Ратцінгера було призначено архієпископом Мюнхенським і Фрайзінгським. А 28 травня 1977 р. його висвятили на єпископа. 27 червня 1977 р. Папа Павло VI звів Джозефа Ратцінгера в ступінь кардинала [9].

У 1980 році Папа Іван-Павло II призначає кардинала Джозефа Ратцінгера головою Папської ради у справах мирян (Pontificium consilium pro laicis). Через рік, 25 листопада 1981 року, Ратцінгер став префектом Конгрегації доктрини віри (Congregatio pro Doctrina Fidei ${ }^{6}$ - орган Святого Престолу, який відповідає за контроль точності католицької доктрини. Посаду він займав до обрання Папою. Згодом кардинала Ратцінгера призначено головою Папської біблійної комісії (Commissio Pontificia de Re Biblica) та Міжнародної теологічної комісії (Commissio Theologica Internationalis) [9].

15 лютого 1982 Ратцінгер залишив пастирські обов'язки в Німеччині і переїхав до Ватикану [9].
Служіння кардинала Ратцінгера на головних посадах у Католицькій церкві було невтомним, і $є$ нездійсненним завданням перерахувати його роботу в просторі біографічної статті. Кардинал Ратцінгер був співавтором основних рішень та документів Івана-Павла II: буде справедливо назвати Джозефа Ратцінгера «сірим кардиналом» Папи Івана-Павла II, адже саме німецький теолог розробляв усі документи. При чому кардинал Ратцінгер зажди залишався у тіні Папи Івана-Павла II. Серед багатьох точок роботи Ратцінгера слід зазначити його роль в якості Голови Комісії з підготовки Катехизму Католицької Церкви (Catechismo della Chiesa Cattolica) [9].

У 1998 році Кардинал Ратцінгер був обраний віце-деканом Колегії кардиналів (Collegio Cardinalizio), a 30 листопада 2002 року - деканом Колегії кардиналів. Ратцінгер входив до комісії Ecclesia Dei, чиїм завданням є формування рішень Католицької церкви із найбільш актуальних питань сучасності.

19 квітня 2005 року на другий день конклаву, в четвертому турі Джозеф Ратцінгер був обраний Папою Римським ${ }^{7}$ і прийняв ім'я Бенедикта ${ }^{8}$ XVI.

Саме ім'я Бенедикт XVI ${ }^{9}$, яке Папа вибрав у день свого обрання на пост префекта Апостольського Престолу, було ознакою особистої прихильності до миру та бажанням відновити єдність у Євpoпi $[7$, n.2]. Бенедикт XVI пояснював свій вибір, 3 однієї сторони, тому що пам'ятав папу Бенедикта XV, «мужнього пророка миру», який керував Церквою під час бурхливих часів Першої світової війни. Крім того, Бенедикт XVI згадував Святого Бенедикта з Нурсії, со-покровителя Свропи, «Патріарха західного чернецтва» [8]. Так, Папа обрав ім'я, яке мало стати фундаментальним орієнтиром для утвердження миру, а також для відновлення єдності Європи з посиланням на християнські корені Європейської культури [8].

${ }^{4}$ Джозеф Ратцінгер автор численних праць, серед яких: «Що означає бути християнином» (1965), «Введення в християнство» (1968), «Віра і майбутнє» (1970), «Принципи християнської моралі» (1975), «Дочко Сіону» (1977), «Бог Ісуса Христа: роздуми про Триєдиного Бога» (1977), «Есхатологія: смерть і вічне життя» (1977), «Принципи католицької теології» (1982), «На початку... Католицьке розуміння історії творіння і гріхопадіння» (1986), «Церква, екуменізм і політика: нові нариси про еклезіологію» (1987), «Служителі вашої радості» (1988), «Погляд на Христа: вправи в вірі, надії і любові» (1989), «Поворотна точка для Європи?» (1991), «Нова пісня Господу: віра в Христа і літургія сьогодні» (1995), «Сіль землі» (1996), «Віхи: Спогади. 1927-1977» (1997), «Дух літургії» (2000), «Бог і світ» (2000), «Істина і толерантність: християнська віра і світові релігії» (2003). Праці Папи Бенедикта XVI стали орієнтиром для багатьох християн, i, звичайно, для тих, хто займається поглибленим вивченням богослов’я. Його праця «Введення в християнство»- стала бестселером. Популярністю також користувалися «Чому я все ще в Церкві?», «Принципи християнської моралі», «Сіль землі» та ін.

5 Журнал став відповіддю на популярність неомарксизму в Західній Європі.

${ }^{6}$ Колишня Свята інквізиція (lat. Inquisitio Haereticae Pravitatis Sanctum Officium - Святий відділ розслідувань єретичної гріховності), перейменована в 1908 році папою Пієм Х у Конгрегацію доктрини віри (Congregatio pro Doctrina Fidei).

7 Бенедикт XVI став найстаршим за віком на момент обрання Папою з часів папи Климента XII (XVIII ст.). Крім того, Бенедикт XVI - перший Папа з часів папи Павла IV (XVI ст.), який був обраний на пост Папи, будучи деканом Колегії кардиналів. Він був 7-м німецьким понтифіком в історії Католицької Церкви.

8 За традицією, яка існує з середини XVI століття, обраний на Папський Престол бере собі нове ім'я. 265-й понтифік прийняв ім'я Бенедикт, ставши 16-м Папою з таким ім'ям. «Бенедикт» в перекладі з латині означає «благословенний».

9 Попередній папа з ім'ям Бенедикт XV був обраний в розпалі Першої світової війни, але не виступав на стороні жодної 3 коаліцій, а засудив Першу світову війну як «непотрібну бійню». 
24 квітня 2005 року відбулась урочиста інавгурація понтифікату, що замінює сьогодні неіснуючу коронацію $^{10} .7$ травня 2005 Папа Римський Бенедикт XVI, що носить титул єпископа Риму, офіційно вступив на кафедру глави Римської єпархії.

3 обранням папою Бенедикта XVI було відомо, що папство Німецького Папи стане досить консервативним, але правління 265-го Папи відзначилось рядом нововведень, реформ та нових ідей.

Слід відзначити, що Бенедикт XVI спочатку був ліберальним богословом, але прийняв консервативні погляди після 1968 року [20]. Його пізні праці захищають традиційне католицьке вчення i цінності. Під час свого папства Бенедикт XVI виступав за повернення фундаментальних християнських цінностей, щоб протистояти посиленій секуляризації в західних країнах [5].

Консерватизм німецького Папи відзначиться i на його суспільно-політичному вченні та політичних закликах. Так, перша енцикліка Бенедикта XVI, «Deus Caritas Est», у відповідності до Католицької соціальної традиції підкреслювала вимогу «правильного порядку суспільства», який має бути «центральним завданням політики» [5, 28 a]. Визнавши обмеження Церкви, Бенедикт XVI наголосив на значенні Католицької Церкви як «етичного резервуару» та закликав до «формування свідомості в політиці і сприяння зростаючому сприйняттю справжніх вимог справедливості та бажання діяти відповідно до справедливості, навіть коли це контрастує з ситуаціями особистого інтересу» [5, 28 a].

Папа Бенедикт також відновив ряд традицій, у тому числі підняв Тридентську месу ${ }^{11}$ на більш помітну позицію [18]. Він зміцнив відносини між
Католицькою церквою та мистецтвом, сприяв використанню латинської мови і знову повернув традиційний папський одяг, за що його назвали «естетичним папою» [3].

У дипломатичній діяльності Бенедикт XVI відзначився «німецьким стилем», а саме делегував ряд своїх дипломатичних обов'язків Державному секретарю Святого Престолу ${ }^{12}$ кардиналу Бертоне ${ }^{13}$. «Німецький стиль» дозволив Папі, доручивши дипломатичну діяльність професійному дипломату, присвятити більше зусиль своїм працям, у яких звертався до світової громади зі своїм баченням майбутнього світового співтовариства, звертаючи увагу на актуальні проблеми сучасності, часто критикуючи меркантилізм сучасного йому суспільства.

Не слід вважати, що Бенедикт XVI відмовився від своїх дипломатичних обов'язків, скоріше дав свободу дій Державному секретарю Святого Престолу кардиналу Тарчізіо Бертоне. Бенедикт XVI i надалі здійснював аудієнції та брав участь у важливих заходах, а за період свого понтифікату Бенедикт XVI здійснив 23 апостольські подорожі ${ }^{14}$.

Щоб зрозуміти підхід Бенедикта XVI до міжнародних відносин та дипломатії Святого Престолу, важливо відзначити філософську та професорську ${ }^{15}$ сутність німецького Папи, як охарактеризував Папу Рацінгера Едвард Пентін: «більше вдома 3 книгами, ніж із дипломатичним корпусом» [17]. А російський журналіст М. Фатєєв так описував Папу Бенедикта XVI: «віддає перевагу молитися, читати і писати» [12]. Без сумніву, Бенедикт XVI - це насамперед великий філософ та по праву про$\phi е с о р^{16}$, який насамперед прагнув поширити Хри-

${ }^{10}$ Останнім Папою, якого увінчували коронацією був Павло VI.

${ }^{11}$ Тридентська меса - одна 3 поширених назв для позначення літургії Католицької церкви - меси, що підтримувалася більшістю латинських Церков до видання Римського місалу, оприлюдненого Папою Павлом VI в 1969 р. після Другого Ватиканського Собору.

12 Державний секретар Святого Престолу або Державний секретар Ватикану - вища адміністративна посадова особа при Святому Престолі. Державний секретар допомагає Папі в управлінні Католицькою Церквою, координуючи різні офіси Святого Престолу та піклуючись про відносини $з$ державами та міжнародними організаціями. Державний Секретаріат виконує всі політичні та дипломатичні функції Святого Престолу.

${ }_{13}^{13}$ Кардинал Тарчізіо Бертоне (It. Tarcisio Bertone) - Державний секретар Святого Престолу з 15 вересня 2006 р. по 15 жовтня 2013 p.

${ }^{14}$ Під час понтифікату Бенедикт XVI здійснив 23 апостольські подорожі, з яких понад дві третини в межах Європи: 1) Німеччина (1821 серпня 2005 року); 2) Польща (25-28 травня 2006 року); 3) Іспанія (8-9 липня 2006 р.); 4) Німеччина (9-14 вересня 2006 р.); 5) Туреччина (28 листопада - 1 грудня 2006 р.); 6) Бразилія (9-14 травня 2007 р.); 7) Австрія (7-9 вересня 2007 року); 8) США (15-21 квітня 2008 р.); 9) Австралія (12-21 липня 2008 р.); 10) Франція (12-15 вересня 2008 р.); 11) Камерун та Ангола (17-23 березня 2009 р.); 12) Йорданія, Ізраїль та Палестинська національна влада (8-15 травня 2009 р.); 13) Чеська Республіка (26-28 вересня 2009 року); 14) Мальта (17-18 квітня 2010 р.); 15) Португалія (11-14 травня 2010 р.); 16) Кіпр (4-6 червня 2010 р.); 17) Великобританія (16-19 вересня 2010 р.); 18) II в Іспанії (6-7 листопада 2010 р.); 19) Хорватія (4-5 червня 2011 року); 20) III в Іспанії (18-21 серпня 2011 р.); 21) Німеччина (22-25 вересня 2011р.); 22) Бенін (18-20 листопада 2011 р.); 23) Мексика та Куба (23-29 березня 2012 р.) [15].

${ }^{15}$ Будучи Папою Бенедикт XVI не припиняв своєї наукової роботи, так з під його руки вийшли праці: «Шлях хреста» (2005), «Християнство і криза культури» (2005), «Ісус з Назарету» (2007), «Ісус, апостоли і рання Церква» (2007), «Отці Церкви: від Климента Римського до св. Августина» (2008) та ін. Також, в період свого понтифікату Бенедикт XVI видав три Енцикліки Deus caritas est (2005), Spe salvi (2007) i Caritas in Veritate (2009) та підготував четвертю Енцикліку Lumen Fidei (2013). Не слід забувати про щорічні Послання до Дипломатичного корпусу при Святому Престолі, Послання з нагоди Дня миру, Послання з нагоди Світового дня молоді, Послання з нагоди Світового дня біженців та ін.

${ }^{16}$ Бенедикт XVI є членом кількох наукових академій Європи і отримав десять почесних докторів з різних університетів, а саме: Коледж св. Томи (США, 1984), Папський католицький університет у м. Ліма (Перу, 1986), Айхштетсько-Інгольштадський католицький університет (Німеччина, 1987), Люблінський католицький університет (Польща, 1988), Наваррський університет (Іспанія, 1998), Вільний Університет пресв. Марії Ассунти в Римі (Італія, 1999), Вроцлавський університет (Вроцлав, Польща, 2000), Клузький університет ім. Бабеша Бойяї (Румунія, 2005), Краківська музична академія (Польща, 2015), Папський університет Івана Павла II (Краків, Польща, 2015). 
стиянське вчення Церкви на світову арену, приділивши більше часу для розробки та розголошення ідей. Це був підхід, який багато в чому виявився перевагою: не обмежуючись протоколами дипломатії, Бенедикт XVI міг більш чітко проголосити християнське послання глобальній аудиторії. Звичайно, такі методи приносили свої плоди, хоча i не без витрат.

Заклики Папи Римського Бенедикта XVI слідують від фінансової кризи до арабської весни та закликів реформувати ООН до організації яка б втілювала в собі прагнення до «вищого рівня міжнародного орієнтира» [6, n. 2], від створення нової системи координат, за якої усі будуть мати право голосу, до створення системи міжнародних відносин, керованої етичними принципами.

За час свого понтифікату Бенедикт XVI, окрім наукових праць та Папських послань, видав три Енцикліки Католицької Церкви: Deus caritas est («Бог є любов», 2005), Spe salvi («Врятовані надією», 2007) i Caritas in Veritate («Милосердя в істині», 2009). Четверта Енцикліка Бенедикта XVI Lumen Fidei («Світло віри», 2013) була написана Бенедиктом XVI, але опублікована за підписом його наступника - Папи Франциска.

11 лютого 2013 Бенедикт XVI під час консисторії з канонізації мучеників Отранто неочікувано повідомив про рішення зректися своїх обов' язків та Апостольського Престолу ${ }^{17}$. Понтифік обгрунтував рішення складністю виконання своєї місії у зв'язку з похилим віком. На момент заяви про відставку Папі Бенедикту XVI було 85 років.
28 лютого 2013 Папа Римський Бенедикт XVI завершив своє служіння і переїхав із Ватикану в папську резиденцію Кастель Гандольфо під Римом. Там він проживав до 2 травня 2013 р., поки не закінчилися ремонтні роботи у ватиканському монастирі Mater Ecclesiae, який знаходиться в межах стін Ватикану ${ }^{18}$. Там у монастирі Mater Ecclesiae Бенедикт XVI живе, присвятивши себе молитві та написанню книг.

Таким чином, Папа Римський Бенедикт XVI - великий інтелектуал Католицької Церкви, автор ряду праць по християнству та трьох Енциклік, більше того - автор реформ Католицької Церкви, який брав участь у Другому Ватиканському Соборі, а $з$ 1980-х займав важливі посади у Ватикані, роблячи свій внесок у розвиток сучасної Католицької церкви.

Хоча може виникати думка, що папство Бенедикта XVI не зосереджується на політиці, а більше на написанні праць, слід відзначити, що у своїх працях Бенедикт XVI піднімав важливі соціальні та етичні питання, а Енцикліка Бенедикта XVI «Caritas in Veritate» [4], яка була відповіддю на фінансову кризу 2008 року, стала світовим бестселером. Варті уваги Послання Бенедикта XVI, які завжди ішли до самої проблеми та піднімали актуальні проблеми світового співтовариства.

Зважаючи на рішення Папи відмовитися, він ясно усвідомив необхідність оновлення Церкви та свою відповідальність, щоб відректися від папства і довірити їі комусь молодшому та більш здатному керувати.

\section{БІБІЛІОГРАФІЧНІ ПОСИЛАННЯ}

1. Allen J. Anti-Nazi Prelate Beatified. / J. Allen. // National Catholic Reporter. - Mode of Access: http://www. nationalcatholicreporter.org/word/word101405.htm\#five. [Accessed: 28.04.2018].

2. Allen J. Cardinal Ratzinger: the Vatican's enforcer of the faith. / J. Allen. - USA: Continuum. 2000.

3. Allen C. Benedict XVI, the best-dressed pope. / J. Allen. // Los Angeles Times. [Electronic resource]. - Mode of Access: http://articles.latimes.com/2013/feb/17/opinion/la-oe-allen-pope-fashion-20130217. [Accessed: 28.04.2018].

4. Benedetto XVI. Caritas in Veritate. / Benedetto XVI. - Città del Vaticano: Libreria Editrice Vaticana, 2009.

5. Benedetto XVI. Deus caritas est. / Benedetto XVI. - Città del Vaticano: Libreria Editrice Vaticana, 2005.

6. Benedetto XVI. Incontro con i membri dell'assemblea generale dell'Organizzazioni delle Nazioni Unite. / Benedetto XVI. // Libreria Editrice Vaticana. - New York. 2008.

7. Benedetto XVI. Nella verità, la pace. / Benedetto XVI. // Messaggio di santo padre Benedetto XVI per la XXXIX Giornata Mondiale della Pace 2006.

8. Benedetto XVI. Ragioni della scelta del nome Benedetto. Audienza Generale.27/04/2005. / Benedetto XVI. // Libreria Editrice Vaticana. [Electronic resource]. - Mode of Access: http://w2.vatican.va/content/benedict-xvi/it/audiences/2005/documents/hf ben-xvi_aud_20050427.html. [Accessed: 28.04.2018].

\footnotetext{
17 Бенедикт XVI був восьмим понтифіком, який відрікся від Апостольського служіння, якщо розглядати лише випадки Пап Климента I, Понтіана, Сільверія, Бенедикта IX, Григорія VI, Целестина V та Грегорія XII, щодо яких є надійні або дуже достовірні історичні джерела. Відставка папи Бенедикта XVI вважається винятковою, оскільки була першою з часів середньовіччя, а саме 31415 року - Григорій ХІІ, змушений подати у відставку в Констанцькій конвенції, щоб закінчити схизму в Західній Церкві - і першим за власним бажанням з 1294 (від Целестин $\mathrm{V}$, який пішов у відставку, щоб стати відлюдником) [11].

1832 травня 2013 р. Бенедикт XVI живе в монастирі Mater Ecclesiae, біля свого наступника папи Франциска у самому Ватикані, що є унікальною та історичною подією в Католицькій церкві: два Папи живуть у стінах Ватикану.
} 
9. Biografia di Sua Santità Benedetto XVI. [Electronic resource]. - Mode of Access: https://w2.vatican.va/content/benedict-xvi/ it/biography/documents/hf_ben-xvi_bio_20050419_short-biography_old.html. [Accessed: 28.04.2018].

10. Dulles A., The Catholicity of the Augsburg Confession. / A. Dulles. // The Journal of Religion, vol. 63, № 4, 1983 , pp. 337-354. 11. Ecco gli altri Papi che hanno abdicato - Da Celestino V a Gregorio XII sono pochi i precedenti nella storia. L'ultimo si ferma al Medioevo. // TgCom24, 2013. [Electronic resource]. - Mode of Access: http://www.tgcom24.mediaset.it/cronaca/ articoli/1081316/ecco-gli-altri-papi-che-hanno-abdicato.shtml. [Accessed: 28.04.2018].

12. Фатеев М. Встречи с Папой Римским Бенедиктом XVI. / М. Фатеев. // Православие и мир [Электронный ресурс]. Режим доступа: http://www.pravmir.ru/vstrechi-s-papoj-benediktom/. [Accessed: 28.04.2018].

13. Jodok T. The Catholic Church: An Underestimated and Necessary Actor in International Affairs. / T. Jodok. // Culture \& Society. Georgetown Journal of International Affairs. Vol. 9, №1. 2008.

14. Landler M., Bernstein R. (2005). A Future Pope Is Recalled: A Lover of Cats and Mozart, Dazzled by Church as a Boy. / M. Landler, R. Bernstein. // The New York Times. [Electronic resource]. - Mode of Access: http://www.nytimes.com/2005/04/22/ world/worldspecial2/a-future-pope-is-recalled-a-lover-of-cats-and-mozart.html. [Accessed: 28.04.2018].

15. Melloni A. Benedetto XVI. / A. Melloni. // Enciclopedia dei Papi. (2013) [Electronic resource]. - Mode of Access: http:// www.treccani.it/enciclopedia/benedetto-xvi_(Enciclopedia-dei-Papi)/. [Accessed: 28.04.2018].

16. Pentin E. The Pope as Diplomat. How the Vatican Does Foreign Policy. / E. Pentin. // Foreign Affairs. [Electronic resource]. - Mode of Access: https://www.foreignaffairs.com/articles/2013-02-27/pope-diplomat. [Accessed: 28.04.2018].

17. Pope Recalls Being German POW. // Fox News. [Electronic resource]. - Mode of Access: http://www.foxnews.com/ story/2005/04/19/pope-recalls-being-german-pow.html. [Accessed: 28.04.2018].

18. Pope set to bring back Latin Mass that divided the Church. // Catholic Citizens. [Electronic resource]. - Mode of Access: https://catholiccitizens.org/news/36625/pope-set-to-bring-back-latin-mass-that-divided-the-church/. [Accessed: 28.04.2018].

19. Sparks J., Follain J., Morgan C. Papal hopeful is a former Hitler Youth. / J. Sparks, J. Follain, C. Morgan. // The Times, 2005. [Electronic resource]. - Mode of Access: https://www.thetimes.co.uk/article/papal-hopeful-is-a-former-hitler-youth-brsgslxjs6t. [Accessed: 28.04.2018].

20. The Pope's Difficult Visit to His Homeland. // Spiegel Online. [Electronic resource]. - Mode of Access: http://www.spiegel.de/ international/germany/disillusioned-german-catholics-the-pope-s-difficult-visit-to-his-homeland-a-787314.html. [Accessed: 28.04.2018].

\section{REFERENCES}

1. Allen, J. (2005). Anti-Nazi Prelate Beatified. National Catholic Reporter. Retrieved from: http://www.nationalcatholicreporter. org/word/word101405.htm\#five

2. Allen, J. (2000). Cardinal Ratzinger: the Vatican's enforcer of the faith. USA: Continuum

3. Allen, C. (2013). Benedict XVI, the best-dressed pope. Los Angeles Times. Retrieved from: http://articles.latimes.com/2013/ feb/17/opinion/la-oe-allen-pope-fashion-20130217

4. Benedetto XVI. (2009). Caritas in Veritate. Città del Vaticano: Libreria Editrice Vaticana [in Italian].

5. Benedetto XVI. (2005). Deus caritas est. Città del Vaticano: Libreria Editrice Vaticana [in Italian].

6. Benedetto XVI. (2008). Incontro con i membri dell'assemblea generale dell'Organizzazioni delle Nazioni Unite. Libreria Editrice Vaticana. New York [in Italian].

7. Benedetto XVI. (2006). Nella verità, la pace. Messaggio di santo padre Benedetto XVI per la XXXIX Giornata Mondiale della Pace [in Italian].

8. Benedetto XVI. (2005). Ragioni della scelta del nome Benedetto. Audienza Generale.27.04.2005. Libreria Editrice Vaticana. Retrieved from: http://w2.vatican.va/content/benedict-xvi/it/audiences/2005/documents/hf ben-xvi_aud_20050427.html [in Italian].

9. Biografia di Sua Santità Benedetto XVI. (2013). Libreria Editrice Vaticana. Retrieved from: https://w2.vatican.va/content/ benedict-xvi/it/biography/documents/hf_ben-xvi_bio_20050419_short-biography_old.html [in Italian].

10. Dulles, A. (1983). The Catholicity of the Augsburg Confession. The Journal of Religion, 63 (4).

11. Ecco gli altri Papi che hanno abdicato - Da Celestino V a Gregorio XII sono pochi i precedenti nella storia. L'ultimo si ferma al Medioevo. (2013). TgCom24. Retrieved from: http://www.tgcom24.mediaset.it/cronaca/articoli/1081316/ecco-gli-altri-papiche-hanno-abdicato.shtml [in Italian].

12. Fatiev, M. (2013). Vstrechy s Papoi Rymskym Benedyktom XVI [Meetings with Pope Benedict XVI]. Pravoslavye y myr. Retrieved from: http://www.pravmir.ru/vstrechi-s-papoj-benediktom/ [in Russian].

13. Jodok T. (2008). The Catholic Church: An Underestimated and Necessary Actor in International Affairs. Culture \& Society. Georgetown Journal of International Affairs, 9 (1) .

14. Landler, M., \& Bernstein, R. (2005). A Future Pope Is Recalled: A Lover of Cats and Mozart, Dazzled by Church as a Boy. The New York Times. Retrieved from: http:/www.nytimes.com/2005/04/22/world/worldspecial2/a-future-pope-is-recalled-alover-of-cats-and-mozart.html

15. Melloni, A. (2013). Benedetto XVI. Enciclopedia dei Papi. Retrieved from: http://www.treccani.it/enciclopedia/benedettoxvi (Enciclopedia-dei-Papi)/ [in Italian].

16. Pentin, E. (2013). The Pope as Diplomat. How the Vatican Does Foreign Policy. Foreign Affairs. Retrieved from: https:// www.foreignaffairs.com/articles/2013-02-27/pope-diplomat

17. Pope Recalls Being German POW. (2005). Fox News.Retrieved from: http://www.foxnews.com/story/2005/04/19/poperecalls-being-german-pow.html 
18. Pope set to bring back Latin Mass that divided the Church. (2006). Catholic Citizens Retrievd from: https://catholiccitizens. org/news/36625/pope-set-to-bring-back-latin-mass-that-divided-the-church/

19. Sparks, J., Follain, J., \& Morgan, C. (2005). Papal hopeful is a former Hitler Youth. The Times. Retrieved from: https://www. thetimes.co.uk/article/papal-hopeful-is-a-former-hitler-youth-brsgslxjs6t

20. The Pope's Difficult Visit to His Homeland. (2011). Spiegel Online. Retrieved from: http://www.spiegel.de/international/ germany/disillusioned-german-catholics-the-pope-s-difficult-visit-to-his-homeland-a-787314.html

\section{Данилюк Іван Васильович}

Аспірант

Київський національний університет імені Тараса Шевченка

01033, м. Київ, вул. Володимирська, 60.

\section{Danyliuk Ivan}

Postgraduate student

Taras Shevchenko National University of Kyiv

Address: 60, Volodymyrska Str., Kyiv, 01033, Ukraine

ORCID: 0000-0002-4313-2746_Email: IvanDanyluk@gmail.com

Цитування: Данилюк I. В. Папа Бенедикт XVI: філософ, політик, дипломат / I. В. Данилюк // Науково-теоретичний альманах «Грані». - 2018. - Т. 21. - № 5. - С. 76-83.

Citation: Danyliuk, I.V. (2018). Papa Benedykt XVI: filosof, polityk, dyplomat [Pope Benedict XVI: philosopher, politician, diplomat]. Scientific and theoretical almanac «Grani», 21(5), 76-83. 